\title{
필리핀의 국가 개발 정책 내 \\ 송금의 영향력 분석
}

목 차

I. 개발협력과 이주, 송금

1. 개발협력과 이주

2. 개발협력과 송금

II. 연구과제

1. 개도국의 개발 정책과 이주의 연계성

2. 필리핀의 개발과 송금

III. 문헌조사

1. 필리핀 개발 정책과 이주, 송금

2. 필리핀 개발과 이주, 송금

IV. 연구방법

1. 일반

2. 데이터

3. 한계점

V. 결과 및 해석

1. 필리핀 중기개발계획(MTPDP)

2. 국정연설(SONA)

VI. 결론

VII. 시사점

참고문헌 


\section{I. 개발협력과 이주, 송금}

\section{1. 개발협력과 이주}

최근 개발협력 분야에서 이주(migration)의 영향력이 급격히 확대되고 있다. 2015년 9월 국제연합(United Nations, 이하 UN) 총회의 개발정상회의에서 공식 채택된 '지속가능개발목 표(Sustainable Development Goals, 이하 SDGs)'는 이주와 개발의 연계성이 강화되고 있다 는 사실을 보여준다. 국제이주기구(International Organization for Migration, 이하 IOM)에 따르면, SDGs의 17 개 목표 중 이주와 관련된 내용이 6 개 목표에 구체적으로 반영되어 있다.

〈표 1〉SDGs 17 개 목표 내 이주 관련 반영 내용

목표 구분

4. 포용적이고 공평한 양질의 교육 보장 및 모두를 위 4.b 2020년까지 지속적으로 전 세계 개도국의 유학생 한 평생학습 기회 증진

5. 양성평등 달성 및 모든 여성과 소녀의 권익 신장

8. 모두를 위한 지속적이고 포용적이며 지속가능한 경 제성장 및 완전하고 생산적인 고용과 양질의 일자 리 증진

10. 국가 내 및 국가 간 불평등 완화

16. 모든 수준에서 지속가능개발을 위한 평화롭고 포 용적인 사회 증진, 모두에게 정의에 대한 접근 제 공 및 효과적이고 책임 있으며 포용적인 제도 구 축

17. 이행수단 강화 및 지속가능개발을 위한 글로벌 파 트너십 활성화

출처: $\mathrm{IOM}$ 홈페이지1)
증가

5.2 여성 및 소녀를 대상으로 한 인신매매, 성적 착취

등 모든 형태의 폭력 근절

8.7 강제노역, 현대판 노예제 및 인신매매 근절

8.8 이주노동자 권리 보호 및 안전한 작업환경 보장특 히 여성 이주노동자)

10.7 체계적인 이주정책 이행

10.c 송금 거래수수료 $3 \%$ 이하로 감소

16.2 아동 인신매매 근절

17.18 개도국 대상 이주 형태(migration status)에 따라 구분된 정보의 이용가능성 증대를 위한 지 원

1) IOM 홈페이지를 참조하기 바란다. (https://unobserver.iom.int/2030-agenda-sustainable-development) (접속 일 201.04.17) 
특히, SDGs 이전의 개발의제인 새천년개발목표(Millennium Development Goals, $\mathrm{MDGs}$ )가 이주 관련 내용을 반영하지 않았던 점을 고려하면, 이러한 SDGs와 이주의 연계성 강화는 이주가 지속가능한 개발에 미치는 긍정적인 영향력과 역할을 국제사회가 공식적으로 인정한 것으로 해석할 수 있다.2)

학계에서도 이주와 개발에 대한 관점은 시대에 따라 낙관론과 비관론이 반복해서 주도하고 있으나(Haas, 2012), 최근에는 그 연계성을 긍정적으로 해석하는 경향이 강하다. 1950-1960년 대는 전쟁 직후 서유럽의 급속한 경제성장에 따라 남유럽, 북아프리카 지역 등에서의 이주가 서유럽이 필요로 하는 노동력을 제공하고, 송금과 기술이전 등을 통해 송출국의 개발에도 기여 한다는 긍정적인 시각이 주도적이었다. 그러나 1970-1990년대에는 이주가 송출국의 송금에 대한 의존도를 고착화시키고, 두뇌 유출에도 영향을 주기 때문에 이주를 부정적으로 바라보는 관점이 지배적이었다. 2000년대 이후부터는 급증하는 송금과 이주 및 송금의 긍정적인 영향력 에 관한 다수의 실증적 연구 자료로 인해, 다시 이주와 개발에 관한 낙관적인 시각이 주도적이다 (Haas, 2012; UNDP, 2009).

또한, UNDP(2009)는 이주와 인간개발지수(Human Development Index, 이하 HDI)의 연계성을 분석한 결과, 송출국의 $\mathrm{HDI}$ 가 낮은 국가일수록 $\mathrm{HDI}$ 가 상대적으로 높은 유입국으로 이동하는 것으로 조사되었다. 이는 최빈국일수록 이주를 통해 얻을 수 있는 교육, 보건, 소득 등의 혜택이 높은 것으로 해석된다.

\section{2. 개발협력과 송금}

$\operatorname{IOM}(2013)$ 에 따르면, 이주는 송출국과 유입국의 경제, 사회, 정치, 문화, 인구 등 다양한 사회적 변화에 영향력을 미치며, 특히 송금은 개발과 이주의 긍정적 연계성을 보여주는 가장 확실한 요소이다(Ratha, 2007). 세계은행(World Bank)에 따르면, 2015년 개발도상국으로 유입된 송금액은 총 4,410억 달러에 달하며, 이는 전 세계 공적개발원조(Official Development Assistance, 이하 ODA) 규모의 3배 이상에 달하는 금액이다(World Bank, 2016a). 또한 송금은 해외직접투자 및 $\mathrm{ODA}$ 에 비해 변동성이 적고, 가계소득이 하락할 때 오히려 증가하는 경향을 보이기 때문에 개도국에 중요한 개발재원 중 하나로 인식된다(Ratha, 2005). 또한, 이주노동자로부터 송금을 받는 가계(migrant household)가 비이주 가계(non-migrant

2) IOM Press Release 'Inclusion of Migration in UN Sustainable Development Goals, a Milestone', 2015.9.25. (https://www.iom.int/news/inclusion-migration-un-sustainable-development-goals-milestone) (접속일 2017.04.17) 
household)에 비해 농업 또는 자영업을 위한 투자에 더 적극적이며, 다수의 연구 자료에서 송금은 개도국의 사회. 경제적 개발 및 빈곤 감소에 긍정적인 영향을 미치는 것으로 조사된다 (Haas, 2005).

\section{II. 연구과제}

\section{1. 개도국의 개발 정책과 이주의 연계성}

국제사회는 SDGs를 포함하여 2006년, 2013년에 개최된 '이주와 개발에 관한 UN 고위급대 화(High-level Dialogue)', UN 회원국의 자발적 참여로 2007년 이후부터 매년 개최되는 '이주 와 개발에 관한 글로벌 포럼(Global Forum on Migration and Development, 이하 GFMD)' 등 다양한 공식행사를 통해 이주를 정책의제로 반영 중에 있다.

한편, 공여국의 경우에도 경제협력개발기구 개발협력위원회 (Organization for Economic and Development Development Assistance Committee, 이하 OECD DAC) 주도로 2000 년대 이후부터 '개발을 위한 정책일관성(Policy Coherence for Development, 이하 PCD)'을 강조하면서 이주를 자국의 개발정책과 연계하기 위한 노력을 강화하고 있으며, 영국 등 다수의 공여국은 개별 보고서를 통해 개발을 위한 이주의 중요성과 연계성을 정책에 반영하고 있다 (DFID, 2007).

그러나 대부분의 이주 송출국이자 개도국의 경우, 자국의 개발 정책 내 이주에 관한 연구 및 인식이 상대적으로 부족하다. 특히, 국제사회에서 2000년대 개발재원으로서 송금에 대한 연구와 관심이 급증하던 기간 동안 아프리카 7 개 국가-베냉, 케냐, 말라위, 말리, 르완다, 탄자니 아-의 '빈곤감소전략문서(Poverty Reduction Strategy Paper, PRSP)'는 이주를 전혀 언급 하지 않고 있다(Booth, 2003). 이는 개발과 송금에 관한 논의가 국제기구와 선진국 위주로 진행된 방면, 개도국이자 송출국은 그 논의 과정에서 상대적으로 소외된 것으로 해석할 수 있다.

\section{2. 필리핀의 개발과 송금}

필리핀은 국제사회에서 대표적인 송출국이며, 이주가 국가 개발에 중요한 요소를 차지하는 
개도국이다. 세계은행(2006)에 따르면, 2015년 기준 필리핀으로 유입된 송금액은 약 280억 달러이며, 인도 690 억 달러, 중국 640 억 달러에 이어 전 세계 3 위를 기록했다. 또한, 2014년 기준 필리핀의 송금액이 국가 전체 국내총생산(Gross Domestic Product, 이하 GDP)의 9.6\%를 차지하는 등 이주가 국가 경제에 미치는 영향력이 매우 큰 것으로 확인된다.

〈그림 1〉 2000-2015년 필리핀 해와유입 송금액

(단위 : 백만불)

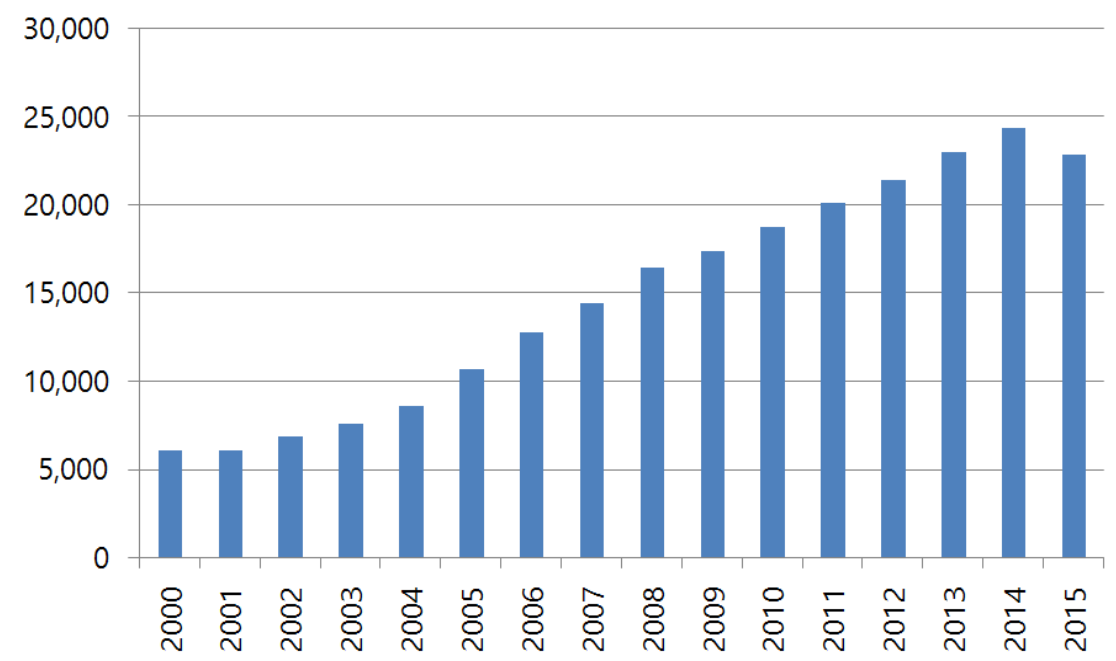

출처: 필리핀 중앙은행(Central Bank Of The Philippines, BSP)

또한, 필리핀 재외동포위원회(Commission on Filipinos Overseas Office of the President of the Philippines, 이하 CFO)에 따르면, 해외에 거주 중인 필리핀 국민은 2013년 기준 $10,238,614$ 명으로 전체 인구의 약 $10 \%$ 에 육박하고 있으며, 이주노동자(Overseas Filipino Workers, OFWs)는 약 240만 명으로 추정된다.

필리핀은 국제사회에서 이주와 개발의 연계를 위한 거버넌스 형성에도 적극적으로 기여하고 있다. 2008년에 아시아 국가 최초로 '이주와 개발에 관한 글로벌 포럼'을 개최하였으며, 2014년 발족한 '재난 국가 이주자에 대한 이니셔티브(Migrants in Countries in Crisis Initiative)'의 의장국으로서, 분쟁 및 자연재해 등으로 인한 재난 국가 이주자의 보호 및 취약성 개선을 위한 가이드라인을 수립 중에 있다. 
2016년 발표된 '이주 거버넌스 지수(Migration Governance Index, 이하 MGI)3)'는 경제 수준, 이주 송출국과 유입국, 지리적 여건 등을 고려하여 총 15 개 대상 국가의 이주정책에 대한 거버넌스 수준을 측정하였다. MGI는 국가별로 1) 제도적 역량, 2) 이주자 인권, 3) 안전하 고 체계적인 이주, 4) 이주노동 관리, 5) 지역/국제적 협력 등 5개 항목 조사 결과를 초기 (nascent), 도입(emerging), 발전(developed), 성숙(mature) 단계로 구분하였다. 필리핀은 이주노동 관리를 제외한 4 개 항목이 성숙 단계로 평가되었으며, 15 개 대상 국가 중 가장 우수한 평가를 받았다. 즉, 이주자의 인권 보호, 안전하고 체계적인 이주 관리 및 지원 등을 포함한 필리핀 정부의 이주정책 및 관리 역량이 상대적으로 매우 우수한 것으로 평가된다.

〈표 2〉2016년 이주거버넌스 지수(MGI)

\begin{tabular}{c|c|c|c|c|c}
\hline 구분 & 제도적 역량 & 이주자 인권 & $\begin{array}{c}\text { 안전하고 } \\
\text { 체계적인 이주 }\end{array}$ & 이주노동 관리 & $\begin{array}{c}\text { 지역국제적 } \\
\text { 협력 }\end{array}$ \\
\hline 바레인 & 도입 & 도입 & 발전 & 도입 & 발전 \\
\hline 방글라데시 & 도입 & 도입 & 도입 & 발전 & 성숙 \\
\hline 캐나다 & 성숙 & 발전 & 발전 & 발전 & 성숙 \\
\hline 코스타리카 & 발전 & 발전 & 발전 & 도입 & 성숙 \\
\hline 독일 & 성숙 & 발전 & 성숙 & 발전 & 성숙 \\
\hline 가나 & 발전 & 도입 & 성숙 & 초기 & 성숙 \\
\hline 이탈리아 & 발전 & 발전 & 도입 & 발전 & 성숙 \\
\hline 멕시코 & 발전 & 도입 & 도입 & 발전 & 발전 \\
\hline 몰도바 & 발전 & 발전 & 성숙 & 발전 & 성숙 \\
\hline 모로코 & 발전 & 도입 & 도입 & 도입 & 발전 \\
\hline 필리핀 & 성숙 & 성숙 & 성숙 & 발전 & 성숙 \\
\hline 남아공 & 성숙 & 발전 & 발전 & 발전 & 성숙 \\
\hline 한국 & 성숙 & 발전 & 성숙 & 발전 & 성숙 \\
\hline 스웨덴 & 발전 & 성숙 & 발전 & 발전 & 성숙 \\
\hline 터키 & 성숙 & 발전 & 도입 & 발전 & 발전 \\
\hline
\end{tabular}

출처: IOM\&EIU (2016) 'The 2016 Migration Governance Index'

이번 연구는 필리핀의 개발 정책에 송금 관련 내용이 반영된 형태 및 성격을 살펴보고, $\mathrm{KOICA}$ 에 주는 시사점을 제시해보고자 한다.

3) IOM \& The Economist Intelligence Unit(EIU), 2016. 


\section{III. 문헌조사}

\section{1. 필리핀 개발 정책과 이주, 송금}

최근 필리핀의 개발 정책과 이주의 연계성은 강화되고 있다. 필리핀 정부가 정권별로 수립하

는 '필리핀 중기개발계획(Medium-Term Philippine Development Plan, 이하 MTPDP)'에

따르면, MTPDP(1999-2004)에는 이주 관련 문단이 총 11개 있는 반면, MTPDP(2011-

2016)은 총 71 개로 약 545\% 증가했다 (김태진, 2016). 또한, 송금에 관한 문단은 2 개에서 11 개로 증가하는 등 필리핀의 개발 정책이 이주와 송금의 중요성을 반영하고 있으며, 그 영향력 은 점차 증가하고 있다 (김태진, 2016).

필리핀 대통령실 산하 $\mathrm{CFO}$ 에 따르면, $\mathrm{MTPDP}(2011-2016)$ 에는 최소 60개의 이주 관련 조항이 포함되어 있다. 또한, $\operatorname{MTPDP}(2004-2010)$ 에는 이주와 관련 내용이 단순히 일자리 창출 및 송금에 국한되어 있는 반면, $\operatorname{MTPDP}(2011-2016)$ 에는 금융교육 프로그램, 재외동포 2 세를 위한 문화 및 국가 전통 이해도 제고, 인재 유입 등 다양한 방면에서 이주와의 연계성을 언급하고 있다(IOM, 2013).

결론적으로, 현재 필리핀 개발 정책 내 이주는 과거와 달리 경제, 사회, 정치, 문화 등 다방면에 서 영향력을 미치고 있으며, 특히 송금과 투자 등 경제적인 부분의 영향력이 강조된다는 특징이 있다 (김태진, 2016).

\section{2. 필리핀 개발과 이주, 송금}

최근 20 년 간 필리핀의 이주노동자 및 송금이 급증함에 따라, 필리핀의 송금과 개발의 연계성 에 관한 많은 연구가 진행되었다. 해외 송금을 받는 필리핀 가계는 생활수준 및 복지가 향상되었 으며, 교육에 대한 투자를 늘렸다(Murata, 2012). 또한, 1997년 아시아 외환위기 당시 필리핀의 가계소득 하락분의 약 $60 \%$ 를 해외 송금이 대체하였으며, 이는 송금이 경제상황이 어려울수록 증가하면서 가계소득 개선에 기여한 것으로 해석된다(Yang, 2007). 


\section{IV. 연구방법}

\section{1. 일반}

필리핀의 개발 정책과 송금의 연계성 분석을 위해 이번 연구는 양적 측면에서 정책 내 송금 이 언급된 문단 수를 조사하고, 개수가 증가/감소함에 따라 연계성도 증가/감소하는 것으로 평가한다.

또한, 문단 내 송금의 의미도 1) 긍정, 2) 부정, 3) 중립으로 구분하였다. 송금 관련 문단의 개수가 증가하더라도, 긍정적인 의미로 사용된 문단이 많은 경우가 그렇지 않은 경우에 비해 송금과 개발의 연계성이 더 강한 것으로 해석한다. 개발 정책 내 송금의 의미를 긍정, 부정, 중립으로 구분하는 방법은 아래와 같다.

〈표 3〉 송금의 의미 구분

\begin{tabular}{c|l|l}
\hline 구분 & \multicolumn{1}{|c|}{ 정의 } & \multicolumn{1}{c}{ 예시 } \\
\hline \multirow{2}{*}{$\begin{array}{c}\text { 긍정 } \\
\text { (부정) }\end{array}$} & $\begin{array}{l}\text { 송금의 긍정적(부정적) 영향력을 표현 } \\
\text { 한 경우 }\end{array}$ & $\begin{array}{l}\text { Overall, consumption fuelled by remittances is } \\
\text { the largest and most stable source of growth } \\
\text { from the demand side. (MTPDP 2011-2016) }\end{array}$ \\
\cline { 2 - 3 } & $\begin{array}{l}\text { 송금 관련 제도 개선 필요성(불필요성) } \\
\text { 을 언급한 경우 }\end{array}$ & $\begin{array}{l}\text { The remittance profiling survey project for } \\
\text { efficient remittance data collection shall be } \\
\text { pushed. (MTPDP 2004-2010) }\end{array}$ \\
\hline \multirow{2}{*}{ 중립 } & 송금 관련 단순 수치 언급 & $\begin{array}{l}\text { In 1993-98, foreign exchange remittances of } \\
\text { OFWs grew at an annual average of 16 } \\
\text { percent. (MTPDP 1999-2004) }\end{array}$ \\
\cline { 2 - 4 } & $\begin{array}{l}\text { 타 개발 분야(노동, 성평등 등) 에서 송 } \\
\text { 금이 부연설명을 위해 언급된 경우 }\end{array}$ & $\begin{array}{l}\text { Remittances from female OFWs worldwide } \\
\text { were relatively lower than from their male } \\
\text { counterparts. (MTPDP 2011-2016) }\end{array}$ \\
\hline
\end{tabular}

출처: 저자 작성

나아가 송금이 구체적으로 개발 정책 내에서 반영된 특성 및 목적을 구분하여, 그 영향력을 세분화하였다. 이는 향후 필리핀의 개발 정책이 송금을 통해 달성하고자 하는 목표를 예측해 볼 수 있는 근거가 될 수 있다. 


\section{2. 데이터}

이번 연구는 필리핀의 개발 정책으로 MTPDP과 국정연설(Speech of Nation Address, 이하 SONA)을 사용한다. 신임대통령이 선출될 때마다 수립하는 MTPDP는 정부의 포괄적인 개발목표 및 프로그램을 포함하는 대표적인 국가 개발 정책이다. 이번 연구에 사용되는 MTPDP는 13대 대통령 조지프 에스트라다(Joseph Ejercito-Estrada)의 MTPDP 19992004, 14대 대통령 글로리아 마카파갈 아로요(Gloria Macapagal-Arroyo)의 MTPDP 2004-2010, 15대 대통령 베니그노 아키노 3세(Benigno S. Aquino III)의 MTPDP 2011-2016로 총 3개이다.

두 번째 개발 정책은 매년 대통령이 직접 국회에서 발표하는 SONA이다. 필리핀 헌법 8항

23 조에 의거하여 대통령의 의무로 규정된 SONA는 매년 대통령이 필리핀의 경제, 정치, 사회 등 전반적인 국정 현황을 설명하고, 임기 내 달성하고자 하는 정부의 정책 목표를 제시한다. 연설의 배경, 발표자, 목적, 범위, 상징성 등을 고려 시, SONA는 필리핀 개발 정책의 일부로 해석할 수 있다.

이번 연구에 사용되는 SONA는 MTPDP와 시간적 비교가 가능하도록, 에스트라다 대통령 (1998-2000), 아로요 대통령(2001-2009), 아키노 3세 대통령(2010-2015)이 임기 중 발표한 모든 SONA를 포함하고, 현재 대통령인 로드리고 두테르테(Rodrigo Duterte)가 2016년 6월 취임 후 발표한 SONA도 현 정부의 이주와 개발에 관한 의지와 관심을 알아볼 수 있는 자료이 므로 데이터에 포함하였다.

\section{3. 한계점}

송금의 질적 분석에서 부정적 의미의 문단은 없었으나 긍정과 중립의 구분이 불분명한 문단 이 일부 있었다. 이 경우에는 중립으로 표시하여 긍정적 문단이 최대한 명확하게 구분되도록 하였지만, 저자의 주관성이 개입될 수 있는 부분이다. 또한, MTPDP 내 송금이 포함된 문단의 개수는 문헌조사를 통해 이전 연구결과(김태진, 2016)를 사용하되, 송금의 긍정, 부정 등 질적인 의미를 이번 연구를 통해 추가적으로 파악하였다. 


\section{V. 결과 및 해석}

\section{1. 필리핀 중기개발계획(MTPDP)}

〈그림 2〉MTPDP(1999-2004) 내 송금 관련 문단 수

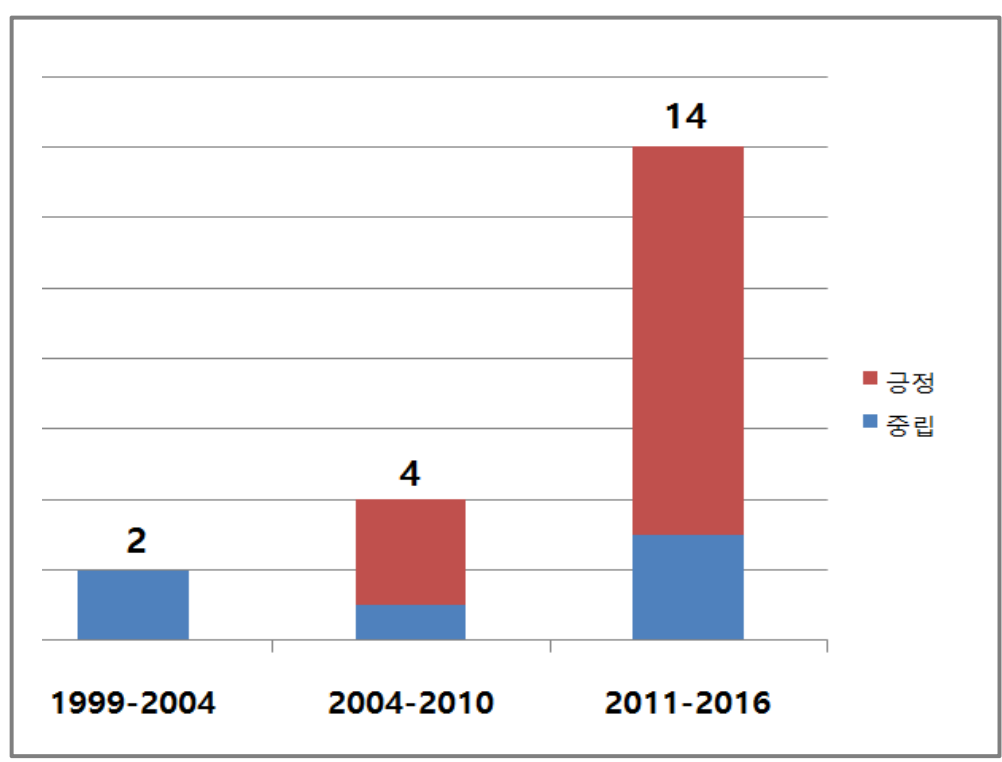

출처: 저자 작성

$\operatorname{MTPDP}(1999-2004)$ 는 송금에 관한 문단이 총 2개 있으나, 모두 단순히 송금액의 증감 추이 및 규모 등을 언급하는 중립적 성격의 문단이기 때문에 개발과의 특별한 연계는 없는 것으로 판단된다.

〈표 3〉MTPDP(1999-2004) 내 송금 관련 문단 내용

\begin{tabular}{c|c|l|c}
\hline 연번 & 구분 & \multicolumn{1}{|c}{ 해당 문단 } & 비고(구분 근거) \\
\hline 1 & 중립 & $\begin{array}{l}\text { 7장. 거시경제 프레임워크 및 개발재원 } \\
\text { In 1993-98, foreign exchange remittances of OFWs } \\
\text { grew at an annual average of 16 percent. It may be } \\
\text { noted that although deployment was highest in 1998, } \\
\text { remittances fell by 14.2 percent from US\$5.74 billion in } \\
1997 \text { to US\$4.93 billion in 1998. }\end{array}$ & 단순 수치 언급 \\
\hline 2 & 중립 & $\begin{array}{l}\text { 7장. 거시경제 프레임워크 및 개발재원 } \\
\text { Total deployment was about 2.7 percent of total } \\
\text { domestic employment in 1998. Moreover, total }\end{array}$ & 단순 수치 언급 \\
\hline
\end{tabular}




\begin{tabular}{l|l|l|c}
\hline 연번 & 구분 & \multicolumn{1}{|c}{ 해당 문단 } & 비고(구분 근거) \\
\hline & $\begin{array}{l}\text { deployment was about 3.8 times bigger than the net } \\
\text { increment in total employment, which was only 196,000 } \\
\text { in 1998. Meanwhile, remittances from the OFWs } \\
\text { accounted for 7.2 percent of GNP in 1998. This was } \\
\text { about 16.7 percent of total export earnings for the same } \\
\text { year. }\end{array}$ & \\
\hline
\end{tabular}

출처: 저자 작성

$\operatorname{MTPDP}(2004-2010)$ 는 송금에 관한 긍정적 문단 3개, 중립적 문단 1 개 포함하고 있다. 특히, 송금의 긍정적인 인식은 정부 차원에서 송금에 관한 정보 취합 기능 강화 및 자연보호를 위한 정부 통합보호지역펀드(Integrated Protected Areas Fund, IPAF)와의 연계, 송금의 우수 인재 유입에 따른 과학기술 발전 등으로 나타나고 있다.

〈표 4〉MTPDP(2004-2010) 내 송금 관련 문단 내용

\begin{tabular}{|c|c|c|c|}
\hline 연번 & 구분 & 해당 문단 & 비고(구분 근거) \\
\hline 1 & 긍정 & $\begin{array}{l}\text { 1장. 무역 및 투자 } \\
\text { The remittance profiling survey project for efficient } \\
\text { remittance data collection shall be pushed. }\end{array}$ & $\begin{array}{l}\text { 송금 관련 제도 개선 } \\
\text { (효율적인 송금 데이터 } \\
\quad \text { 취합의 필요성) }\end{array}$ \\
\hline 2 & 긍정 & $\begin{array}{l}\text { 3장. 환경 및 천연자원 } \\
\text { Facilitate the remittance of the Integrated Protected } \\
\text { Areas Fund (IPAF) or the funds generated inside } \\
\text { Protected Areas, to the PAMB; }\end{array}$ & $\begin{array}{l}\text { 송금의 긍정적 영향력 } \\
\text { (정부 환경보호 } \\
\text { 지역펀드와의 연계) }\end{array}$ \\
\hline 3 & 중립 & $\begin{array}{l}\text { 9장. 노동 } \\
\text { Meanwhile, the country was able to generate } 2.624 \\
\text { million job orders overseas or an average of } 875,000 \\
\text { deployment per year, contributing approximately } \\
\text { US } \$ 20.1 \text { billion worth of remittances to the country. }\end{array}$ & 타 개발 분야 내 부연설명 \\
\hline 4 & 긍정 & $\begin{array}{l}\text { 9장. 과학 및 기술 } \\
\text { Return migration and reverse flows of income will be } \\
\text { stimulated by encouraging remittances and investments } \\
\text { that will be channeled toward development efforts. } \\
\text { Diaspora and networks of Filipino S\&T workers } \\
\text { abroad shall increasingly be tapped as an important } \\
\text { medium for knowledge sharing. }\end{array}$ & $\begin{array}{l}\text { 송금의 긍정적 영향력 } \\
\quad \text { (인재 유입 및 } \\
\text { 지식공유와의 연계) }\end{array}$ \\
\hline
\end{tabular}

출처: 저자 작성 
$\operatorname{MTPDP}(2011-2016)$ 는 송금 관련 문단이 14 개이며, 이 중 긍정적인 문단이 11 개로 이전 MTPDP 대비 급증하고 있다. 특히 송금의 일반적인 긍정적 효과인 경제성장, 투자 및 소비와의 연계, 외자 유치를 포함하여, 송금의 적극적 활용을 위한 금융 문해 캠페인(Financial literacy campaign), 금융 시스템 개선 등 다양한 방식의 송금의 역할과 지원 방안을 포함한다. $\mathrm{MTPDP}$ 의 시간적 흐름에 따라 송금 관련 문단이 증가한 것과 동시에 송금과 개발의 긍정적 연계성 수준과 범위도 확대되었다.

〈표 5〉MTPDP(2011-2016) 내 송금 관련 문단 내용

\begin{tabular}{|c|c|c|c|}
\hline 연번 & 구분 & 해당 문단 & 비고(구분 근거) \\
\hline 1 & 긍정 & $\begin{array}{l}\text { 1장. 포용적 성장 추구 } \\
\text { Thanks to overseas remittances, surpluses on current } \\
\text { account have been run consistently since } 2003 \text {. }\end{array}$ & $\begin{array}{l}\text { 송금의 긍정적 영향력 } \\
\text { (재정흑자와의 연계) }\end{array}$ \\
\hline 2 & 긍정 & $\begin{array}{l}\text { 2장. 거시경제 정책 } \\
\text { Overall, consumption fuelled by remittances is the } \\
\text { largest and most stable source of growth from the } \\
\text { demand side. }\end{array}$ & $\begin{array}{l}\text { 송금의 긍정적 영향력 } \\
\text { (소비 증가와의 연계) }\end{array}$ \\
\hline 3 & 긍정 & $\begin{array}{l}\text { 2장. 거시경제 정책 } \\
\text { Private construction likewise grew } 13.3 \text { percent, } \\
\text { boosted by remittance fuelled residential construction } \\
\text { as well as the need for more supply of office space. } \\
\text { Likewise, private consumption, which constitutes the } \\
\text { largest proportion of GDP on the expenditure side, } \\
\text { continued its stable growth at } 5.9 \text { percent, fuelled by } \\
\text { remittances from overseas workers }\end{array}$ & $\begin{array}{l}\text { 송금의 긍정적 영향력 } \\
\text { (주택/건축 경기, } \\
\text { 소비와의 연계) }\end{array}$ \\
\hline 4 & 긍정 & $\begin{array}{l}\text { 2장. 거시경제 정책 } \\
\text { Notwithstanding the effects of the global financial crisis, } \\
\text { GDP in } 2009 \text { rose by } 1.1 \text { percent, a figure within the } \\
\text { target of } 0.8-1.8 \text { percent, making the Philippines one } \\
\text { of the few economies in the region to register positive } \\
\text { performance amidst the recession. GNP on the other } \\
\text { hand, grew by } 4 \text { percent, fuelled by robust inflows of } \\
\text { overseas remittances. }\end{array}$ & $\begin{array}{l}\text { 송금의 긍정적 영향력 } \\
\text { (GNP 증가와의 연계) }\end{array}$ \\
\hline 5 & 긍정 & $\begin{array}{l}\text { 2장. 거시경제 정책 } \\
\text { In 2010, coming from a low base and boosted by the } \\
\text { rebound in world trade, quarterly GDP grew } 7.3 \\
\text { percent. Remittance-driven consumption and the } \\
\text { pick-up in investments and net exports (from significant } \\
\text { negative contributions in 2009) boosted growth. }\end{array}$ & $\begin{array}{l}\text { 송금의 긍정적 영향력 } \\
\text { (소비 증가와의 연계) }\end{array}$ \\
\hline 6 & 긍정 & $\begin{array}{l}\text { 2장. 거시경제 정책 } \\
\text { The current account position has shifted to structural } \\
\text { surpluses in large part due to the resilience of overseas }\end{array}$ & $\begin{array}{l}\text { 송금의 긍정적 영향력 } \\
\text { (재정흑자와의 연계) }\end{array}$ \\
\hline
\end{tabular}




\begin{tabular}{|c|c|c|c|}
\hline 연번 & 구분 & 해당 문단 & 비고(구분 근거) \\
\hline & & $\begin{array}{l}\text { remittances, increased services receipts from business } \\
\text { process outsourcing, and steady tourism receipts. }\end{array}$ & \\
\hline 7 & 긍정 & $\begin{array}{l}\text { 2장. 거시경제 정책 } \\
\text { Overseas Filipino (OF) remittances have been steadily } \\
\text { growing even when the global financial crisis broke out. } \\
\text { In } 2010 \text {, remittances coursed through banks amounted } \\
\text { to US } \$ 18.8 \text { billion, an increase by } 8.2 \text { percent from the } \\
\text { level recorded in previous year. }\end{array}$ & $\begin{array}{l}\text { 송금의 긍정적 영향력 } \\
\text { (외화 유치와의 연계) }\end{array}$ \\
\hline 8 & 긍정 & $\begin{array}{l}\text { 2장. 거시경제 정책 } \\
\text { Furthermore, policymakers will need to focus on } \\
\text { leveraging remittances as a tool for economic } \\
\text { development. While remittances are private transfers, } \\
\text { the government can ensure that the policy environment } \\
\text { is conducive to the use of remittances for investment in } \\
\text { well-considered financial products, in productive } \\
\text { activities such as entrepreneurial undertaking as well } \\
\text { as in better housing, education, and healthcare for } \\
\text { remitters and their beneficiaries. Improving the financial } \\
\text { education of the overseas Filipino community and } \\
\text { implementing measures to further promote the flow of } \\
\text { remittances through the financial system would help } \\
\text { catalyze the developmental role of remittances. }\end{array}$ & $\begin{array}{l}\text { 송금의 긍정적 영향력 } \\
\text { (경제성장과의 연계) }\end{array}$ \\
\hline 9 & 중립 & $\begin{array}{l}\text { 3장. 경쟁력 있는 산업 및 서비스 } \\
\text { Tourism is regarded as the fourth largest contributor to } \\
\text { foreign exchange receipts. The top three are } \\
\text { electronics and semiconductors, overseas Filipino } \\
\text { remittances and BPO. }\end{array}$ & $\begin{array}{c}\text { 타 개발 분야 내 } \\
\text { 부연설명 }\end{array}$ \\
\hline 10 & 긍정 & $\begin{array}{l}\text { 3장. 경쟁력 있는 산업 및 서비스 } \\
\text { Promote Entrepreneurship among Ofs The DFA, DOLE, } \\
\text { DOF, Commission on Filipinos Overseas, and the } \\
\text { Bangko Sentral shall conduct financial literacy } \\
\text { campaign overseas to educate and orient OFs } \\
\text { regarding their investment and remittance options } \\
\text { which may include special bond issuances and related } \\
\text { financial instruments. }\end{array}$ & $\begin{array}{c}\text { 송금 관련 제도 개선 } \\
\text { (송금에 대한 } \\
\text { 금융교육의 필요성) }\end{array}$ \\
\hline 11 & 긍정 & $\begin{array}{l}\text { 6장. 회복력 있고 포괄적인 금융 } \\
\text { Together with improved macroeconomic conditions, } \\
\text { the steady inflow of remittances from OFWs, a minimal } \\
\text { investment exposure to foreign structured products and } \\
\text { a low dependence on exports, these reforms allowed } \\
\text { the financial system to avoid the worst difficulties } \\
\text { encountered by other economies during the 2007- } \\
2008 \text { financial crisis. }\end{array}$ & $\begin{array}{c}\text { 송금의 긍정적 영향력 } \\
\text { (금융 위기 대응과의 } \\
\text { 연계) }\end{array}$ \\
\hline
\end{tabular}




\begin{tabular}{|c|c|c|c|}
\hline 연번 & 구분 & 해당 문단 & 비고(구분 근거) \\
\hline 12 & 긍정 & $\begin{array}{l}6 \text { 장. 회복력 있고 포괄적인 금융 } \\
\text { Consequently, about } 37 \text { percent of municipalities in the } \\
\text { Philippines do not even have a banking office and can } \\
\text { be considered either unserved or underserved with } \\
\text { respect to a broad range of critical financial services } \\
\text { such as credit, savings, payment transfers, remittances } \\
\text { and insurance. }\end{array}$ & $\begin{array}{l}\text { 송금 관련 제도 개선 } \\
\text { (금융 서비스 개선의 } \\
\text { 필요성) }\end{array}$ \\
\hline 13 & 긍정 & $\begin{array}{l}\text { 6장. 회복력 있고 포괄적인 금융 } \\
\text { One way to address this is through the promotion of } \\
\text { inclusive finance wherein everyone has access to all } \\
\text { financial services including, but not limited to deposit } \\
\text { account services, credit services, remittances, and } \\
\text { insurance services. }\end{array}$ & $\begin{array}{c}\text { 송금 관련 제도 개선 } \\
\text { (금융 서비스 개선의 } \\
\text { 필요성) }\end{array}$ \\
\hline 14 & 중립 & $\begin{array}{l}\text { 8장. 사회 개발 } \\
\text { Remittances from female OFWs worldwide were } \\
\text { relatively lower than from their male counterparts. }\end{array}$ & $\begin{array}{c}\text { 타 개발 분야 내 } \\
\text { 부연설명 }\end{array}$ \\
\hline
\end{tabular}

출처: 저자 작성

한편, MTPDP(2011-2016)에서 아키노 3세 대통령은 경제 개발을 위한 송금의 역할 및 정부의 지원 의지를 아래와 같이 구체적이고 명확하게 나타내고 있다.

"Furthermore, policymakers will need to focus on leveraging remittances as a tool for economic development." (MTPDP 2011-2016)

이 문단은 이전 MTPDP와 차별화되며 가장 의미 있는 부분이다. 아키노 3 세 대통령은 송금이 민간 재원이나, 정부가 주도적으로 송금의 확대 및 활용을 위한 정책적 지원을 해야 하며, 이를 위한 제도 수립, 데이터 취합 및 관련 부처의 역량 강화를 강조한다. 따라서 $\operatorname{MTPDP}(2011-2016)$ 은 송금과 개발의 연계에 관한 필리핀 정부의 정책적 의지를 확실하게 표명한 최초의 MTPDP로 볼 수 있다.

최근 3개의 MTPDP를 통해 확인한 결과, 지난 15 년 간 필리핀 정부는 개발 정책 내 송금의 중요성 및 의미를 점차 확대한 것으로 평가된다. 특히, 개발 정책 내 송금의 의미와 역할은 단순히 송금의 규모, $\mathrm{GDP}$ 내 비중 등 단순한 수치와 투자와의 연계 및 외화 유치 등 송금의 일반적이고 수동적인 효과에 대한 언급에서 송금과 개발의 연계를 위한 다양한 방안 및 정부의 적극적인 역할 등 능동적인 방향으로 표현되었다. 


\section{2. 국정연설(SONA)}

〈그림 3〉 국정연설(SONA) (1998-2016) 내 송금 관련 문단 수

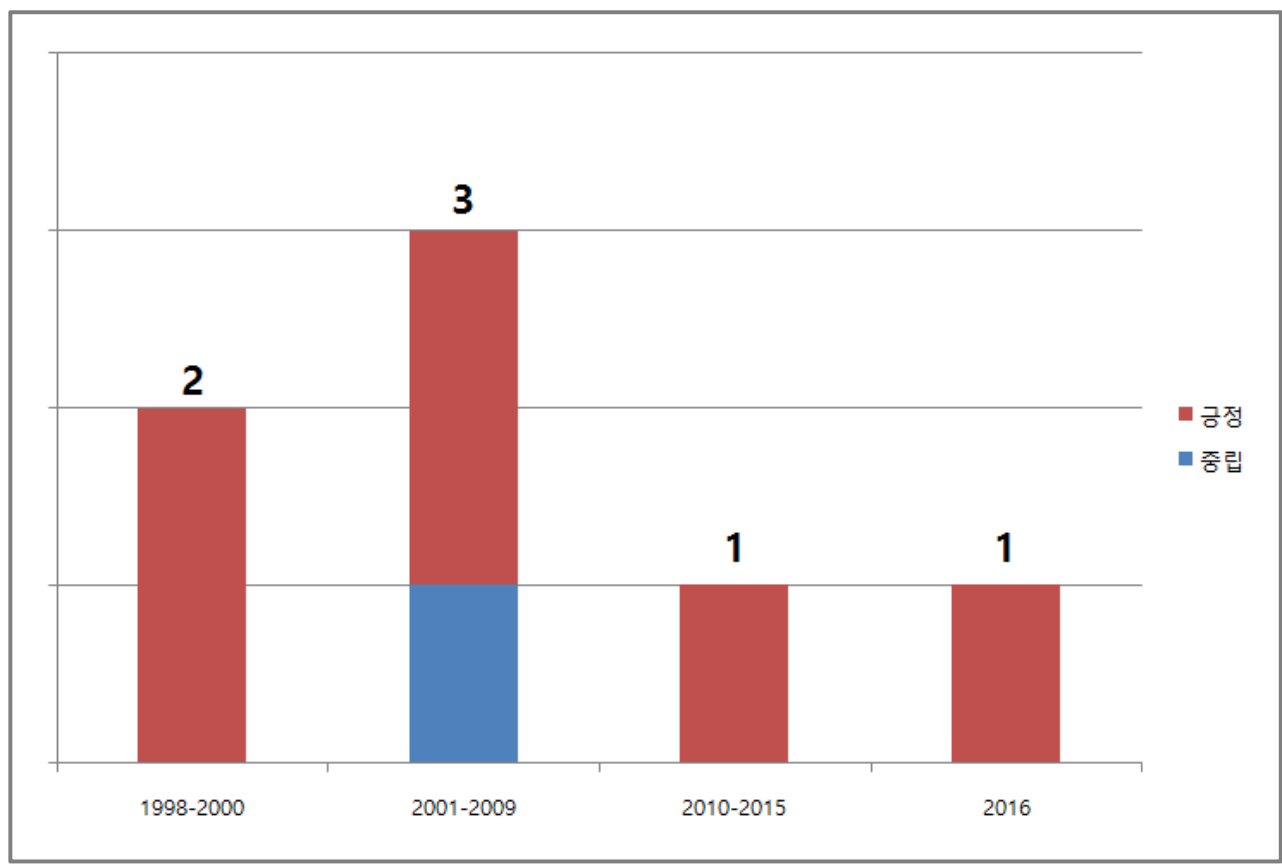

출처: 저자 작성

대통령별 SONA 내 송금에 관한 문단은 1-2회로서, 시간적 흐름에 따른 변화도 거의 없다. 에스트라다 대통령은 3번의 SONA에서 총 2번 송금에 대해 언급하였다. 1999년 SONA에서 그는 필리핀 이주노동자가 아시아 외환위기로 인한 어려운 여건에서 필리핀의 국민총생산 (Gross National Product, GNP) 성장에 기여했으며, 그들은 ‘국가 경제 구원자(economic savoirs)'로 표현하였다. 2000년 SONA에서는 송금이 필리핀의 기록적인 외화 보유액 유치에 기여하였다고 평가하였다.

아로요 대통령은 총 10 번의 SONA에서 송금에 대해 3 번 언급하였다. 2007 년에는 일자리 창출에 따른 경제 효과와 비교하기 위해 단순한 수치만 언급하였으며, 2009년에는 송금의 긍정 적인 경제 효과 및 송금 활용의 의지 등을 표명하였다.

아키노 대통령은 6 번의 SONA에서 송금을 1 번 언급하였으나, 아래와 같이 송금에 인한 경제성장을 말하면서 이주 자체는 자국 내 희망을 잃어버린 이들이 선택한 수단이라고 부정적으 로 말한다. 
“....you would realize that a significant portion of this growth was fueled by remittances from Filipinos who had lost hope in our country." (SONA, 2015)

현 필리핀 정부의 두테르테 대통령은 취임 직후 2016년 7월 25일 발표한 SONA에서 송금에 관해 1 번 언급하였지만, 내용적인 측면에서 이전 대통령이 언급한 송금과는 확연히 다르다.

"To help ensure that the hard-earned money of our Overseas Filipinos are put into productive use, a mandatory financial education for all migrant and their communities shall be pursued along with incentives to encourage entrepreneurship among them.” (SONA, 2016)

두테르테 대통령은 송금의 효용 증대를 위해 이주자 대상 의무화된 금융 교육과 이주자가 속한 커뮤니티 내에서 인센티브와 함께 기업가 활동에 대한 지원이 뒷받침되어야 한다고 말한 다. 이 문단은 최근 20 년 동안 4 명의 대통령의 SONA 중 송금의 활용을 위한 구체적인 방법을 제시한 최초의 문단이다. 정치, 경제, 사회 등 국가의 모든 분야 정책을 총망라하는 SONA에서 20년 만에 최초로 송금이라는 특정 이슈를 구체적으로 다뤘다는 점은 매우 유의미하다.

또한, 향후 두테르테 대통령의 임기 6년 동안 송금에 대한 강조가 계속 확대될 것으로 예측되 며, 금융교육과 기업가 활동이라는 2 가지 분야에서 두테르테 대통령이 어떤 정책을 제시하는지 살펴볼 필요가 있을 것이다.

\section{VI. 결론}

이번 연구에서 필리핀 개발 정책 내 송금의 영향력은 점차 확대되고 있는 것으로 평가된다. 필리핀의 가장 대표적인 국가 개발 정책인 MTPDP는 시간적 흐름에 따라, 경제성장 및 외화 유치 등 송금의 기본적인 역할에 대해 단순히 언급하는 수준에서 최근에는 송금과 투자의 연계, 송금의 효용 증대를 위한 금융 교육, 금융 시스템 개선 등 적극적이고 창의적인 방법으로 송금을 설명하고 있다.

특히, 아키노 대통령이 MTPDP 2011-2016에서 정책입안자들이 경제성장의 도구로 송금을 적극적으로 활용해야 한다고 직접적으로 명시한 점은 매우 의미 있는 부분이며, 송금과 개발의 
연계에 관한 필리핀 정부의 강한 의지를 보여준다.

반면, $\mathrm{SONA}$ 에서는 송금에 관한 언급이 거의 없었으며, $\mathrm{MTPDP}$ 와 같은 송금의 영향력 확대를 확인할 수 없었다. 그러나 현 두테르테 대통령의 SONA는 지난 20년 동안의 SONA에 서 최초로 송금의 효과성 제고를 위해 금융교육과 기업가정신 진흥이라는 구체적인 방법을 제시했다는 점에 주목할 필요가 있다. 두테트테 대통령은 임기 동안 이주 및 송금과 관련한 다양하고 적극적인 정책을 제시할 것으로 예상되며, 실제 진행 중이다.

한 예로, 2016년 8월 15일 필리핀 고용노동부(Department of Labor and Employment)는 두테르테 대통령의 직접 지시에 따라 산하기관인 해외노동청(Philippine Overseas Employment Administration, 이하 POEA)에 이주노동자가 필요로 하는 모든 서비스를 한 곳에서 이용할 수 있는 원스톱서비스센터(One-stop service center)를 개설하였다.4) 외교부 의 여권 업무, 해외근로자복지청(Overseas Welfare Workers Administration)의 회원증 발급 및 갱신 등 총 14 개 부처 및 공공기관의 서비스를 이용할 수 있는 이번 센터는 이주노동자 의 이동비용 감소와 서비스 이용시간 단축에 기여할 것으로 예상된다. 이주노동자를 대상으로 하는 이러한 편의 제공은 궁극적으로 이주노동자 확대를 통한 송금의 증가로 연계될 수 있다.

또한, 두테르테 대통령은 2016년 9월 5일 라오스 비엔티안에서 개최된 아세안 정상회의에 참석하기 위한 출국연설(departure speech)5)에서도 이주자의 인권보고와 복지 증진을 위한 주변국의 협조를 요청하겠다고 언급하였고, 일부 해외언론은 그가 이주노동자를 부패와 학대로 부터 보호할 것이 확실시 된다고 보도하고 있다6). 이주노동자에 대한 인권보호와 권익신장은 안정적인 이주노동과 지속적인 송금으로 연계될 수 있는 부분이다.

결론적으로 두테르테 대통령이 SONA에서 언급한 송금의 중요성과 마찬가지로, 향후 필리 핀 정부는 이주, 송금 및 개발의 연계를 더욱 강화하고 이를 위한 정부 정책을 수립할 것으로 예측된다.

4) POEA 홈페이지를 참조하기 바란다. (http://www.poea.gov.ph/news/2016/08-5.pdf) (2017.04.17)

5) 필리핀 관보(The Official Gazette)를 참조하기 바란다.

(http://www.gov.ph/2016/09/05/departure-speech-of-president-rodrigo-roa-duterte-sept-5-2016/) (2017.04.17)

6) 더 가디언(The guardian) 홈페이지를 참조하기 바란다.

(https://www.theguardian.com/world/2016/oct/08/rodrigo-duterte-first-100-days-philippines-president) (2017.04.17) 


\section{VII. 시사점}

이주는 개발 분야에서 핵심적인 의제로 부상하고 있다. 오늘날 이주는 송금, 기술이전과 같은 전통적으로 인식되어 온 긍정적 영향력뿐만 아니라, 최근에는 중동, 북아프리카 지역의 난민 이슈로 인한 인권 등의 측면에서도 많은 주목을 받고 있다.

그러나 개발과 이주에 대한 국제사회의 관심과 기대가 증가한 반면, 우리 정부의 개발협력 정책과 이주 간의 연계는 많이 부족해 보인다. 국제개발협력기본법, 제2차 국제개발협력 기본계 획, 중점협력국 대상 국가협력전략(Country Partnership Strategy, CPS) 등 다양한 정부의 개발협력 정책에서 이주에 관한 내용은 거의 없다.

반면, 국제사회는 우리 정부에 개발과 이주 연계의 필요성을 강조하고 있다. $\mathrm{OECD} \mathrm{DAC은}$ 2012년 발표한 1차 동료평가(peer review) 결과에서 한국 정부의 'PCD' 부족을 지적하였고, 2015년 2차 동료평가 중간점검(mid-term review)에서도 PCD 강화를 위한 이주와 개발의 연계를 언급하였다.

이러한 환경에서 필리핀은 우리 정부가 개발과 이주의 연계를 시도해 볼 수 있는 가장 적합한 국가 중 하나이다. MGI를 통해 확인된 것처럼 필리핀의 이주정책은 타 개도국에 비해 매우 체계적이며, 필리핀 정부의 관심과 지원도 향후 높아질 것으로 예상된다.

또한, 필리핀은 24 개 중점대상국 중 하나이며, 법무부 자료에 따르면 2016년 기준 국내에 5 만 4천여 명의 필리핀 이주민이 거주하고 있는 것으로 조사되었다. 아울러, 이주민 출신 최초로 국회에서 활동한 이자스민(Jasmine Lee) 전 국회의원 등에 의해 필리핀 이주자에 대한 국민의 인식도 타 개도국이자 송출국에 비해 상대적으로 높다.

개발협력과 이주, 송금을 연계할 수 있는 방법은 다양하다. ODA 자금을 통해 필리핀 본국으 로 귀환한 이주노동자에 대한 재통합 교육 및 창업을 지원할 수 있으며, 필리핀 정부의 이주정책 수립 및 통계 관리 시스템 구축 등도 ODA 사업으로 진행할 수 있다. 또한 한국 내 은행과 협력하여 해외이주 근로자들의 송금 시 적용되는 거래비용을 낮추는 방법도 SDGs 달성과 연계되는 효과적인 방법이 될 수 있다.

2017년 11월 예정된 $\mathrm{OECD} \mathrm{DAC}$ 의 제 2 차 동료평가에서도 이주와 $\mathrm{PCD}$ 에 대한 지적이 예상된다. 우리 정부 차원에서 개발협력과 이주의 연계를 위한 연구와 검토, 사업 발굴이 시급한 시점이다. 


\section{〈참고문헌〉}

김태진. 2016. "필리핀 이주정책과 개발 정책의 연계성 분석." 서울대 석사학위논문.

Booth, D. 2003. “Introduction and overview.” Development Policy Review 21(2). DFID. 2007. "Moving out of Poverty - making migration work better for poor people.” London: DFID, available at http://www.migrationdrc.org/ publications/ other_publications/Moving_Out_of_Poverty.pdf (접속일: 2017.04.17)

Haas, de Hein. 2012. "The Migration and Development Pendulum: A Critical View on Research and Policy". International Migration Vol.50(3).

2005. "International Migration, Remittances and Development: Myths and Facts". Third World Quarterly Vol.26(8): 1269-1284.

IOM. 2013. "Country Migration Report: The Philippines 2013.” Geneva: IOM, available at https:/www.iom.int/files/live/sites/iom/files/Country/docs/ CMReport-Philipines-2013.pdf. (접속일: 2017.04.17)

IOM \& EIU. 2016. "The 2016 Migration Governance Index," available at https://publications.iom.int/system/files/pdf/migration_governance_index_ 2016.pdf (접속일: 2017.04.17)

Murata, Akira. 2011. Effects of Remittances on Household Expenditure Inequality and Education Expenditure: Evidence from the Philippines. Doctoral thesis (DPhil), Brighton: University of Sussex.

OECD. 2009. "Building Blocks for Policy Coherence for Development.” Paris: OECD, available at http://www.oecd.org/pcd/44704030.pdf. (접속일: 2017.04.17) Ratha, Dilip. 2005. "Workers' Remittances: an Important and Stable Source of External Development Finance.” Washington, D.C.: World Bank. 2007. "South-south Migration and Remittances." Washington, D.C: World Bank.

UNDP. 2009. "Migration, Poverty Reduction Strategies and Human Development." Human Development Research Paper. New York: UNDP, available at http://hdr.undp.org/en/content/migration-poverty-reduction-strategies-a nd-human-development (접속일: 2017.04.17) 
World Bank. 2016a. "Migration and Remittances: Recent Developments and Outlook." Migration and Development Brief 26. Washington D.C.: World Bank, available at http://documents.worldbank.org/curated/en/788241468180260116/ pdf/105075-PUB-ADD-ISBN-DOI-PUBLIC-MigAndDevelopment Brief April2016-9781464809132.pdf (접속일: 2017.04.17)

World Bank. 2016b. "Migration and Remittances FactBook 2016.” Washington D.C.: World Bank.

Yang. 2007. Are Remittances Insurance? Evidence from Rainfall Shocks in the Philippines. The World Bank Economic Review, Vol.21(2): 219-48.

IOM 홈페이지: www.iom.org (접속일: 2017.04.17)

IOM Press release: https://unobserver.iom.int/2030-agenda-sustainable-development (접속일: 2017.04.17)

POEA Press release: http://www.poea.gov.ph/news/2016/08-5.pdf (접속일: 2017.04.17) The guardian: https://www.theguardian.com/world/2016/oct/08/rodrigo-dutertefirst-100-days-philippines-president (접속일: 2017.04.17)

The Official Gazette(필리핀 관보 2016.09.05 Departure speech: http://www.gov. ph/2016/09/05/departure-speech-of-president-rodrigo-roa-dutertesept-5-2016(접속일: 2017.04.17) 